\title{
Measuring Service Quality of Public Dental Health Care Facilities in Kelantan, Malaysia
}

Type:

Article

Abstract:

This study investigates patients' expectations and perceptions of service quality in public dental health care and measures their "satisfaction gap." This descriptive study involved 481 dental outpatients in Kelantan, Malaysia. A modified SERVQUAL 20-item instrument was used to assess patients' expectations before and perceptions after receiving dental treatment. The "satisfaction gap" was then measured. Results showed that patients visiting for management of dental pain were more satisfied $(P=.007)$ than those visiting with appointment. The most significant service quality dimensions were related to responsiveness, assurance, and empathy of the dental health care providers. There was a significant difference between the patients' expectations and their perceptions of service provided $(\mathrm{P}<.01)$ with regard to all dimensions. In conclusion, dental service providers should give emphasis to the compassionate and emotional aspects of care and to remember that they are integral components of quality service.

\begin{tabular}{|c|l|}
\hline Author & $\begin{array}{l}\text { ・ John, J. } \\
\text { Y Yatim, F. M. } \\
\end{array}$ \\
\hline Source & Asia-Pani, S. A \\
\hline ISSN & $1010-5395$ \\
\hline DOI & $10.1177 / 1010539509357341$ \\
\hline Volume (Issue) & $23(5)$ \\
\hline Page & $742-753$ \\
\hline Year & 2011 \\
\hline
\end{tabular}

Keyword:

patient satisfaction,SERVQUAL,oral health care,expectation,perception quality of life,patient satisfaction,consumer perceptions, medical-care expectations,scale

Please Cite As:

JOHN, J., YATIM, F. M. \& MANI, S. A. 2011. Measuring Service Quality of Public Dental Health Care Facilities in Kelantan, Malaysia. Asia-Pacific Journal of Public Health, 23, 742-753. 
URL:

- http://apps.webofknowledge.com search via Accession No >>000296239100011

- http://www.scopus.com/inward/record.url?eid=2-s2.079955993098\&partnerID=40\&md5=ff08af4efca9d9a113473749cb49036a

- http://www.scopus.com/inward/record.url?eid=2-s2.079955993098\&partnerlD=40\&md5=ff08af4efca9d9a1 13473749cb49036ahttp://a ph.sagepub.com/content/early/2010/02/26/1010539509357341

- http://www.deepdyve.com//p/sage/measuring-service-quality-of-public-dentalhealth-care-facilities-in-JHqxxeNYUN 